\title{
Sprawozdanie z Forum Dialogu Publicznego w Nowym Sączu, odbywającego się w 2017 r. pod hasłem „Kto spotyka Jezusa Chrystusa, spotyka judaizm”
}

Przez stulecia Sądecczyzna zamieszkiwana była przez wspólnoty i grupy etniczne o różnym pochodzeniu i religii. Żydzi pojawili się tu prawdopodobnie w XV w. Jednak dramat Holocaustu na długie lata wymazał społeczność żydowską z mapy Nowego Sącza.

Cykl spotkań seminaryjnych odbywających się w ramach Forum Dialogu Publicznego w Nowym Sączu pod nazwą „Kto spotyka Jezusach Chrystusa, spotyka judaizm”, miał na celu przybliżenie Sądeczanom historii i religii żydowskiej. Na fundamencie wiary biblijnego Izraela powstały bowiem dwie wielkie religie: chrześcijaństwo i judaizm rabiniczny ${ }^{1}$. Ideą serii spotkań było przybliżenie ich wspólnych korzeni. Tytuł programu został zaczerpnięty ze słów Jana Pawła II, które wypowiedział 17 listopada 1980 r. w Moguncji².

Organizatorami Forum Dialogu Publicznego w Nowym Sączu było Archiwum Narodowe w Krakowie Oddział w Nowym Sączu, Kościół Ewangelicko-Augsburski w Nowym Sączu oraz Fundacja Euros - Wiatr ze Wschodu. Partnerami wydarzenia był Zbór Chwały Bożej Kościoła Zielonoświątkowego w Nowym Sączu, Sądecki Sztetl, Pedagogiczna Biblioteka Wojewódzka w Nowym Sączu oraz Stowarzyszenie Profesjonalnego Samorządu.

Inicjatorem wydarzenia i głównym prelegentem był Arkadiusz Herzberg, pracownik sądeckiego Oddziału Archiwum Narodowego w Krakowie, pomysłodawca programu „Kto spotyka Jezusa Chrystusa, spotyka judaizm”. Spotkania odbywały się w Parafii Przemienienia Pańskiego Kościoła Ewangelicko-Augsburskiego w Nowym Sączu przy ul. Pijarskiej 21.

W ramach forum zaplanowane były cztery spotkania seminaryjno-wykładowe (wraz $\mathrm{z}$ prezentacją multimedialną) z następującymi referatami: 1. Instytucje judaizmu biblijnego (15 września), 2. Instytucje chrześcijańskie dziedziczone z judaizmu. Jezus Chrystus - Żyd praktykujący (13 października) 3. Konflikt między Synagogą a Kościołem w I wieku naszej ery (17 listopada), 4. Od judaizmu biblijnego do judaizmu rabinicznego (8 grudnia $)^{3}$. Po ostatnim wykładzie zaplanowany był panel dyskusyjny na temat dialogu międzyreligijnego.

Podczas pierwszej prelekcji wyeksponowane zostały dzieje starożytnego Izraela, którego początki sięgają XX/XIX w. p.n.e. ${ }^{4}$ Podkreślono rolę Mojżesza w procesie kształtowa-

${ }^{1}$ Chrześcijaństwo a judaizm rabiniczny. Historia poczatków oraz wczesnego rozwoju, pod red. Hershela Shanksa, przekł. Waldemar Chrostowski, wyd. 2, Warszawa 2016, s. 7.

${ }^{2}$ Bóg, Biblia, Mesjasz. Z księdzem profesorem Waldemarem Chrostowskim rozmawiaja: Grzegorz Górny i Rafat Tichy, wyd. 3, Warszawa 2015, s. 394.

${ }^{3}$ Termin ostatniego spotkania został przesunięty na 26 stycznia 2018 r. z przyczyn niezależnych od organizatorów.

${ }^{4}$ Władysław Pałubicki, Jan Iluk, Małżeństwo i rodzina $w$ dawnym judaizmie i starożytnym chrześcijaństwie, Gdańsk 1995, s. 15. 
nia świadomości narodowej starożytnego Izraela. W trakcie krótkiego rysu historycznego zaakcentowano okres niewoli babilońskiej, podczas którego judaizm wypracował schematy funkcjonowania poza granicami własnego kraju, które ostatecznie umożliwiły mu zachowanie tożsamości religijnej i przetrwanie narodu. W dalszej części omówiono sanktuaria biblijnego Izraela, od Namiotu Zgromadzenia, przez Świątynię króla Salomona, aż do Świątyni Heroda. Szczególną uwagę zwrócono na rolę instytucji świątyni w judaizmie okresu Starego i Nowego Testamentu. Wiele miejsca poświęcono kształtowaniu się kanonu Biblii Hebrajskiej (Tanach) i powstaniu Septuaginty (LXX), pierwszego tłumaczenia na język grecki świętych Pism Hebrajskich. Na zakończenie pierwszej sesji wykładowej dokonano charakterystyki judaizmu okresu Drugiej Świątyni. Wskazano, iż obraz religii żydowskiej jest zróżnicowany i zawiły ${ }^{5}$. „Składają się nań odmienne w różnych środowiskach żydowskich interpretacje tych samych przepisów Prawa i rytów, zróżnicowane formy kultu i przekonania teologiczne, inne oczekiwania eschatologiczne i różne spojrzenia na role narodu wybranego w historii politycznej i religijnej" $"$.

W ramach drugiego spotkania, we wstępie przeprowadzono charakterystykę źródeł do dziejów wczesnego Kościoła oraz dokonano analizy procesu kształtowania się Ewangelii. Główna część prelekcji została poświęcona postaci Jezusa Chrystusa. Na podstawie wybranych fragmentów Nowego Testamentu oraz stanu badań w tym zakresie przeprowadzono studium, którego celem było odkrycie żydowskich korzeni Jezusa z Nazaretu, który według tradycji i religii był synem Izraela. W drugiej części wykładu wskazano na instytucje chrześcijańskie dziedziczone z judaizmu, m.in. na elementy liturgii, credo, sakramenty. Interesujące, z punktu widzenia prelegenta, ale również w opinii słuchaczy, było zaprezentowanie koncepcji prof. Wojciecha Gajewskiego z Uniwersytetu Gdańskiego w kwestii uczestnictwa pierwszych chrześcijan w kulcie ofiarnym w Świątyni Jerozolimskiej’

Trzeci wykład został poświęcony poszukiwaniom przyczyn rozejścia się Kościoła i Synagogi w I w. n.e. Wstępem do rozważań było wprowadzenie do źródeł, które odsłaniają kulisy rozejścia się dwóch religii i stwierdzenie, iż chrześcijaństwo jako religia „powstało i rozwijało się w pierwszych dziesięcioleciach I wieku całkowicie w obrębie Izraela"8. Omawiając początki chrześcijaństwa, wyeksponowano skomplikowane relacje chrześcijaństwa i judaizmu. Skalę problemu zdefiniował ks. prof. Mariusz Rosik, stwierdzając: „Dlatego nie wystarczy mówić jedynie o relacji Kościół - Synagoga. Należy zawsze uwzględnić, który z nurtów Kościoła i Synagogi brany jest pod uwagę. Inaczej bowiem do judaizmu

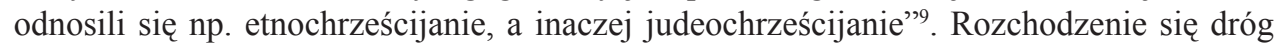
chrześcijaństwa i judaizmu było rozłożone w czasie. Zjawisko to nie było ani pojedyn-

${ }^{5}$ Mariusz Rosik, Judaizm u poczqtków ery chrześcijańskiej, Wrocław 2008, s. 7.

${ }^{6}$ Ibidem, s. 7.

${ }^{7}$ Wojciech Gajewski, Judaistyczne korzenie chrześcijaństwa. Stosunek judeochrześcijan do instytucji i zwyczajów judaizmu okresu drugiej Światyni, „Gdański Rocznik Ewangelicki” 2007, t. 1, s. 9-32.

${ }^{8}$ Wojciech Gajewski, Kościól a Synagoga: poczatki kryzysu. Przyczyny rozejścia się Kościoła i Synagogi w I wieku, „Gdański Rocznik Ewangelicki” 2008, t. 2, s. 40.

${ }^{9}$ Mariusz Rosik, Zarzewie konfliktu między Kościotem a Synagoga (do 135) roku, [w:] Jezus i chrześcijanie w źródłach rabinicznych. Perspektywa historyczna, społeczna, religijna i dialogowa, pod red. Krzysztofa Pilarczyka i Andrzeja Mrozka, Kraków 2012, s. 83. 
czym wydarzeniem historycznym, ani nie odbywało się na jednej płaszczyźnie. W trakcie prezentacji skierowano optykę głównie na przyczyny teologiczne. Mniej miejsca poświęcono czynnikom społecznym. Polityczne powody konfliktu były jedynie tłem rozważań. Na zakończenie wykładu odniesiono się do modlitwy Szmoneesre (Osiemnaście błogosławieństw), jednej z głównych modlitw żydowskich, a w szczególności do błogosławieństwa pod nazwą birkat ha-minim. W rzeczywistości było ono przeklęciem m.in. chrześcijan i przypieczętowało rozłam pomiędzy obiema wspólnotami.

Ostatni referat, zatytułowany „Od judaizmu biblijnego do judaizmu rabinicznego”, miał na celu przybliżyć przemiany, które zachodziły w łonie judaizmu po zburzeniu Świątyni Jerozolimskiej w 70 r. n.e. Przeważająca część wystąpienia poświęcona została omówieniu najważniejszych ugrupowań/stronnictw (haireseis) występujących w złożonym i wielopostaciowym judaizmie przełomu er. Główny akcent spotkania został położony na prezentację przebudowy życia religijnego Żydów po tragedii 70 r. Judaizm pozbawiony Świątyni, centralnego punktu swojej religii, musiał podjąć wysiłek w celu zachowania własnej tożsamości narodowej i religijnej. Judaizm okresu Drugiej Świątyni był wielowymiarową mozaiką różnych przekonań teologicznych i politycznych. Po zburzeniu Jerozolimy, a wraz z nią Świątyni, znaczna część autorytetów żydowskich osiedliła się w okolicy miejscowości Jabne, by tam dokonać wnikliwej przebudowy swojej religii. Odtąd obserwujemy judaizm w nowej zunifikowanej formie, w której nie będzie już miejsca m.in. dla judeochrześcijan. Od tego momentu rozwija się judaizm rabiniczny.

Klamrą spinającą cykl wykładów forum był panel dyskusyjny zatytułowany „Między judaizmem a chrześcijaństwem. Debata o potrzebie spotkania”. Do udziału w panelu zaproszono pastora Jacka Orłowskiego z Kościoła Zielonoświątkowego w Nowym Sączu, księdza Dariusza Chwastka z Kościoła Ewangelicko-Augsburskiego w Nowym Sączu oraz Pana Artura Franczaka, dyrektora Pedagogicznej Biblioteki Wojewódzkiej w Nowym Sączu. Celem panelu dyskusyjnego była próba odpowiedzi na pytanie, czy wspólne korzenie chrześcijaństwa i judaizmu mogą być podstawą dialogu między obiema religiami w XXI w. Uczestnicy panelu podkreślali potrzebę organizowania wydarzeń lokalnych o charakterze edukacyjnym, popularyzujących wiedzę na temat innych narodowości, kultur i religii. Ponadto, przywołując słowa Jana Pawła II, zwrócono uwagę, iż dialog chrześcijaństwa z judaizmem nie jest dialogiem międzyreligijnym, ponieważ judaizm jest dla chrześcijaństwa rzeczywistością wewnętrzną.

Cykl prelekcji „Kto spotyka Jezusa Chrystusa, spotyka judaizm” cieszył się sporym zainteresowaniem wśród mieszkańców miasta. Frekwencja zdecydowanie przekroczyła oczekiwania organizatorów i samego pomysłodawcy forum. Spotkania były doskonałą okazją do zapoznania się z historią starożytną Izraela i historią początków chrześcijaństwa, znaną mimo wszystko, jedynie wąskiej grupie historyków. Podsumowując, projekt zakończył się sukcesem, a postawione cele i założenia zostały osiągnięte. Z pewnością Forum Dialogu Publicznego było głosem domagającym się dialogu pomiędzy dwiema wielkimi religiami: chrześcijaństwem i judaizmem. 